Agroforestry Systems, August 2018, Volume 92, Issue 4, pp 1035-1046

DOI:10.1007/s10457-017-0124-3

\title{
Land use change and soil carbon pools: evidence from a long-term silvopastoral experiment
}

\author{
Dario Fornara ${ }^{1}$, Rodrigo Olave ${ }^{2}$, Paul Burgess ${ }^{3}$, Aude Delmer ${ }^{3}$, Matthew Upson ${ }^{3}$ \& Jim \\ McAdam $^{1}$ \\ ${ }^{1}$ Agri-Food \& Biosciences Institute (AFBI), Newforge Lane, Belfast BT9 5PX, UK \\ ${ }^{2}$ Agri-Food \& Biosciences Institute (AFBI), Large Park, Hillsborough, BT26 6DR, UK \\ ${ }^{3}$ Cranfield University, Cranfield, Bedfordshire, MK43 OAL
}

\section{Corresponding author:}

Dr. Dario Fornara, Agri-Food \& Biosciences Institute,

Newforge Lane, BT9 5PX, Belfast, UK

Tel: +44 (0)2890255335

Email: dario.fornara@afbini.gov.uk

\begin{abstract}
Multi-functional silvopastoral systems provide a wide range of services to human society including the regulation of nutrients and water in soils and the sequestration of atmospheric carbon dioxide $\left(\mathrm{CO}_{2}\right)$. Although silvopastoral systems significantly contribute to enhance aboveground carbon (C) sequestration (e.g. C accumulation in woody plant biomass), their long-term effects on soil $\mathrm{C}$ pools are less clear. In this study we performed soil physical fractionation analyses to quantify the $C$ pool of different aggregate fractions across three land use types including (1) silvopastoral system with ash trees (Fraxinus excelsior L.), (2) planted woodland with ash trees, and (3) permanent grassland, which were established in 1989 at Loughgall, Northern Ireland, UK. Our results show that 26 years after the conversion of permanent grassland to either silvopastoral or woodland systems, soil C (and N) stocks (0$20 \mathrm{~cm}$ depth) did not significantly change between the three land use types. We found, however, that permanent grassland soils were associated with significantly higher $\mathrm{C}$ pools (g $\mathrm{C} \mathrm{kg}^{-1}$ soil; $\mathrm{P}<0.03$ ) of the large macro-aggregate fraction ( $>2 \mathrm{~mm}$ ) whereas soil $\mathrm{C}$ pools of the micro-aggregate $(53-250 \mu \mathrm{m})$ and silt $\&$ clay $(<53 \mu \mathrm{m})$ fractions were significantly higher in the silvopastoral and woodland systems $(P<0.05)$. A key finding of this study is that while tree planting on permanent grassland may not contribute to greater soil $C$ stocks it may, in the long-term, increase the $\mathrm{C}$ pool of more stable (recalcitrant) soil micro-aggregate and silt $\&$ clay fractions, which could be more resilient to environmental change.
\end{abstract}


Keywords: agroforestry, carbon sequestration, ecosystem services, soil aggregates, soil physical fractionation, soil nitrogen.

\section{Introduction}

The conservation and maintenance of significant soil organic carbon (C) pools across humanmanaged ecosystems worldwide is crucial for sustaining food production and the delivery of multiple ecosystem services (FAO and ITPS 2015). Over the last two decades there has been increasing evidence that both ecosystem service delivery (including soil C sequestration) and biological diversity greatly benefit from the diversification of agricultural landscapes (Fischer et al. 2008; Phalan et al. 2011; Bommarco et al. 2013). Diversification includes, for example, the adoption of silvopastoral systems where livestock graze between spaced trees (Mosquera-Losada et al. 2009). Although silvopastoral systems provide a wide range of ecosystem services including the regulation of nutrient and water in soils and aboveground sequestration of atmospheric $\mathrm{CO}_{2}$ (Montagnini and Nair 2009; Tully et al. 2012; Torralba et al. 2016), it is not clear to what extent these agroforestry systems also promote soil $C$ accumulation. Previous meta-analysis studies show that tree planting on permanent grassland tends to reduce rather than increase soil organic C content and stocks (Guo and Gifford 2002; Laganiere et al. 2010).

Significant changes in soil C pools typically occur over many years and are influenced by climatic conditions (i.e. tropical vs. temperate regions) and by multiple management factors including tree/shrub species identity and soil disturbance (i.e. tillage vs. no-tillage), which all contribute to increase variability in soil C stock estimates (Oelbermann et al. 2004; Li et al. 2012). For example, across tropical regions, rates of soil $C$ sequestration may vary from 5-10 kg C ha-1 in extensive tree-intercropping systems of arid and semiarid tropics to 100-250 kg C ha-1 in species-intensive multi-strata shaded perennial systems of humid tropics (Nair et al. 2009). In an 18-year-old agroforestry system in a Mediterranean region of Southern France hybrid walnuts (Juglans regia $\times$ nigra L.) accumulated $\sim 248 \mathrm{~kg} \mathrm{C} \mathrm{ha}^{-1} \mathrm{yr}^{-1}$ more than a durum wheat (Triticum turgidum) arable cropping system (Cardinael et al. 2015). A recent study across six agroforestry sites in France shows average soil $C$ sequestration rates of $240 \mathrm{~kg} \mathrm{C} \mathrm{ha}^{-1} \mathrm{yr}^{-1}$ (Cardinael et al. 2017). Findings from a 14-year-long study in a more temperate maritime climate of England show how $\mathrm{C}$ stocks (estimated on an equivalent soil mass (ESM) basis) in the topsoil (0-10 cm depth) of agroforestry and woodland systems were $10 \%$ and $22 \%$ lower, respectively, than soil C stocks in permanent grassland (Upson et al. 2016). Recent results from a meta-analysis study (Shi et al. 2013) show that tree planting on permanent grassland does not necessarily lead to significant reductions in soil $\mathrm{C}$ stocks.

The high variability in soil $\mathrm{C}$ sequestration rates as shown across several agroforestry studies could be partly explained by 'legacy' effects of the soils used as 'control' treatment (i.e. tilled vs. no-tilled soils), which strongly influence soil $C$ pools. For example, repeatedly tilled 'control' soils would have reduced soil C pools when compared to no-tilled 'control' soils. Carbon stock estimates especially when comparing different land uses can also be 
affected by soil depth (Upson and Burgess 2013). It could be, however, that variation in soil C sequestration among different agroforestry systems ultimately depends on how $\mathrm{C}$ will accumulate and stabilize into different soil aggregate fractions some of which are more recalcitrant than others (von Lützow et al. 2007). A review study, which compared soil C sequestration in tropical and temperate agroforestry systems, shows that although tropical systems accumulate more organic matter detritus, soil $\mathrm{C}$ stocks do not necessarily increase because of the faster turnover rate of this labile $C$ detritus pool (Oelbermann et al. 2004). Similarly, Cardinael et al. (2015) reported that most of the additional C accumulation benefit of agroforestry when compared to an arable cropping (control) system was related to increases in coarse soil organic fractions, which are considered labile soil C fractions.

So far there have been very few studies, which specifically addressed potential changes in $\mathrm{C}$ pools across different soil aggregate fractions especially when comparing agroforestry systems with other land use types (Upson et al. 2016; Osei et al. 2017). Here we specifically measured and compared total mass and the $C$ and nitrogen $(N)$ content of four different soil aggregate fractions (i.e. large macro-aggregates (> $2 \mathrm{~mm}$ ), macroaggregates $(2 \mathrm{~mm}-250 \mu \mathrm{m})$, micro-aggregates $(250-53 \mu \mathrm{m})$, and silt \& clay $(<53 \mu \mathrm{m})$ across three land use types (i.e. permanent grassland, silvopastoral system, and woodland plantation), which were all established in 1989 at Loughgall, Northern Ireland, UK. After 26 years of different land use we expect that the presence of broadleaved trees in both silvopastoral and woodland sites would be associated with significant accumulation of plant litter in surface soils especially in the ash woodland. Thus our study aims to assess and clarify whether the accumulation of organic detritus from woody plants will have increased the C pool of ('labile') large macro-aggregate soil fractions (Paul at al. 2003; Huang et al. 2011) when compared to permanent grassland.

\section{Study site}

The study site is located at the Agri-Food and Biosciences Institute (AFBI) research centre in Loughgall, County Armagh (lat $54.4^{\circ} \mathrm{N}$, long $6.6^{\circ} \mathrm{W}$ ), Northern Ireland, UK approximately 35 $\mathrm{m}$ a.s.l. Annual temperatures over the last 20 years average $9.75^{\circ} \mathrm{C}$ while mean annual rainfall at the site has been recorded as about $880 \mathrm{~mm}$ without any pronounced year to year variability. Soils at Loughgall are classified as Brown Earth on Red Limestone Till (BERLT; Avery 1980), with a soil pH ranging between 7.0 and 8.3, and clay content between 30 and $45 \%$ (Cruickshank 1997).

A long-term silvopastoral experiment was established in 1989 and consists of (1) three silvopastoral plots planted with ash trees (Fraxinus excelsior L.), (2) three woodland plots planted with ash trees (Fraxinus excelsior), and (3) three permanent grassland plots (Fig. 1). The nine plots were established as part of the UK National Network Experiment (NNE), which includes multiple agroforestry systems (Sibbald et al. 2001). The site and surrounding area are predominantly characterized by drumlin hills and the previous land use was mainly pasture where grasslands are dominated by perennial ryegrass (Lolium perenne L.). The nine silvopastoral + woodland + permanent grassland plots are laid out as 
three blocked pair treatments where plots within each block are approximately adjacent to each other. Plot size ranged approximately from 0.12 to 0.56 ha. The agroforestry (i.e.

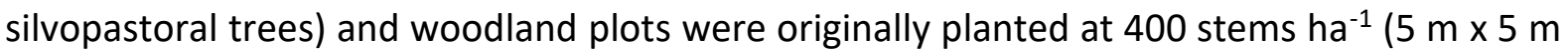
spacing) and 2500 stems ha-1 $^{-1} 2 \mathrm{~m} \times 2 \mathrm{~m}$ spacing) respectively (Fig. 1).
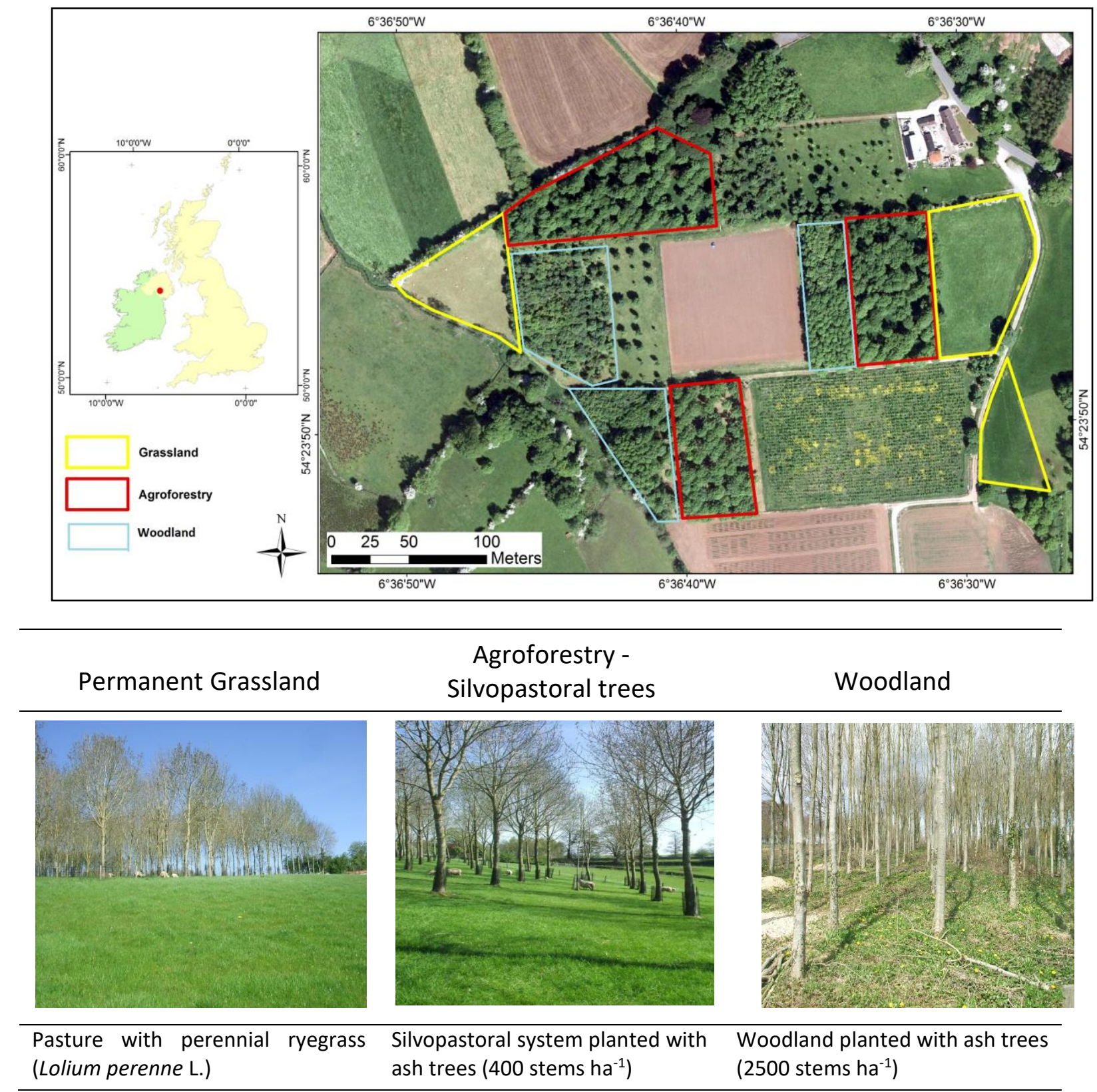

Fig. 1. Location of the study site and details of the three land use types (i.e. permanent grassland, silvopastoral system and planted woodland) established at Loughgall, Northern Ireland, UK in 1989.

Silvopastoral plots were managed under a common protocol covering tree protection, rate of fertiliser, sward height of grasses, pruning and thinning regimes. The overall density of each silvopastoral plot was reduced with thinning regimes to 265 stems ha $^{-1}$ in 2004 and 170 stems ha-1 in 2009 with the stumps still remaining in the ground. Woodland plots received 
minimal management except for thinning and pruning, which were applied in 2009 to improve the quality of the trees, reducing tree density to an average of 1100 stems ha $^{-1}$. In the period between 1989 and 2000 fertiliser application occurred at rates of $120 \mathrm{~kg} \mathrm{~N} \mathrm{ha}^{-1}$ $\mathrm{yr}^{-1}$ in silvopastoral and grassland plots and thereafter reduced to $30 \mathrm{~kg} \mathrm{~N} \mathrm{ha}^{-1} \mathrm{yr}^{-1}$. Sheep grazing occurs in the pasture of both silvopastoral and grassland plots from April to November each year (stocking rate is 12 ewes ha-1). In 2015, 26 years after planting, average DBH (diameter at breast height) of ash trees in the silvopastoral and woodland plots was $31.2 \mathrm{~cm}$ and $21.9 \mathrm{~cm}$ with average stand heights of $16.5 \mathrm{~m}$ and $15.6 \mathrm{~m}$ respectively.

\section{Methods}

Soil sampling

In June 2015, within each plot, samples were taken for soil organic carbon (SOC) and bulk density analysis at $0-10$ and $10-20 \mathrm{~cm}$ depth at each of 10 locations along a transect at intervals of $5 \mathrm{~m}$ in each of the replicate blocks, producing a total of 180 samples. Soil bulk density was measured by collecting a known volume of soil $\left(39.25 \mathrm{~cm}^{3}\right)$ using a metal ring pressed into the soil. Plant roots, organic detritus and stones were removed by sieving the soil through a $2 \mathrm{~mm}$ mesh size. The SOC of the samples (50-100 $\mathrm{mg}$ ) were determined using a LECO (Laboratory Equipment Corporation) CHNS 932 Elemental Analyser. The amount of organic (as opposed to inorganic carbon) is determined after removing the carbonate section by acidification.

In August 2015 a total of ten soil samples $(5 \mathrm{~cm}$ soil core diameter) were also collected between 0-10 and 10-20 cm depth within each experimental plot for soil physical fractionation analyses. Soil samples from each treatment plot were mixed and homogenized to give one composite sample. Fresh soils were sieved through $8 \mathrm{~mm}$ mesh size before airdried for 5 days. Soil samples were then passed through a series of wet sieving procedures to separate bulk soil into (1) large macro-aggregates (>2 mm), (2) macro-aggregates ( $2 \mathrm{~mm}$ - $250 \mu \mathrm{m}),(3)$ micro-aggregates $(250-53 \mu \mathrm{m})$, and primary soil particles or silt \& clay $(<53$ $\mu \mathrm{m})$. Soil physical fractionation analyses were performed following established protocols from literature (Tisdall and Oades 1982; Cambardella and Elliott 1993). The proportion of each fraction was calculated based on the initial soil mass of $100 \mathrm{~g}$ of bulk soil. Each soil fraction was then analysed for total C (\%) and N (\%) using a LECO Trumac CN Analyser (St Joseph, MI, USA), at a working temperature of $1350{ }^{\circ} \mathrm{C}$. In August 2015 , five soil samples (8 $\mathrm{cm}$ diameter) were also randomly collected between 0-10 and 10-20 cm depth intervals within each plot for soil bulk density measurements. Soil bulk density was measured as the ratio between air-dried (stone-free) soil and soil volume. Note that this study mainly focuses on the quantification of different soil $C$ pools and not root $C$ pools, which also significantly contribute to overall belowground $\mathrm{C}$ stocks.

\section{Data analysis}

We used a mixed effects ANOVA in which the three experimental blocks were treated as random effects and the treatment factors (i.e. land use type and soil depth level) were 
included as fixed effects. Potential treatment effects were tested on $\mathrm{C}$ and $\mathrm{N}$ content (\%) as well as on $\mathrm{C}$ and $\mathrm{N}$ pools of different soil physical fractions. Final models were produced using restricted maximum likelihood (REML) method. We checked that final models conformed to modeling assumptions and we used posthoc Tukey's tests to search for significant differences between factor levels (e.g. land use types). All analyses were performed using JMP version 9.0.0 (SAS Institute, Cary, North Carolina, USA, 2010).

\section{Results}

Soil bulk density, carbon and nitrogen contents

We found that mean bulk density of the soil samples collected in June 2015 at a depth of 0$20 \mathrm{~cm}$ was significantly higher in the silvopasture $\left(1.13 \mathrm{~g} \mathrm{~cm}^{-3} ; \mathrm{P}<0.001\right)$ than in the grassland $\left(1.02 \mathrm{~g} \mathrm{~cm}^{-3}\right)$ and the woodland $\left(0.99 \mathrm{~g} \mathrm{~cm}^{-3}\right)$ plots. Overall across all land uses bulk density at a depth of $0-10 \mathrm{~cm}\left(1.02 \mathrm{~g} \mathrm{~cm}^{-3}\right)$ was lower $(P<0.05)$ than that at $10-20 \mathrm{~cm}(1.08$ $\mathrm{g} \mathrm{cm}^{-3}$ ). The mean organic carbon content per $100 \mathrm{~g}$ of soil in the silvopasture varied with depth and treatment $(P<0.001)$ but there was no significant interaction (Table 1$)$. The mean SOC declined from $4.82 \mathrm{~g} \mathrm{C}\left(100 \mathrm{~g} \mathrm{soil}^{-1}\right.$ at $0-10 \mathrm{~cm}$ to $3.17 \mathrm{~g} \mathrm{C}(100 \mathrm{~g} \text { soil })^{-1}$ at $10-20$ $\mathrm{cm}(\mathrm{P}<0.05)$. The value for the pasture $\left(4.50 \mathrm{~g} \mathrm{C}(100 \mathrm{~g} \mathrm{soil})^{-1}\right)$ was greater than that for the silvopasture $\left(3.54 \mathrm{~g} \mathrm{C}\left(100 \mathrm{~g}_{\mathrm{goil}}\right)^{-1}\right)$ at $0-20 \mathrm{~cm}(\mathrm{P}<0.05)$. The quantity of SOC per $10 \mathrm{~cm}$ interval declined with depth (Table 2). Calculating SOC on the basis of a fixed depth, there was no significant $(P>0.2)$ effect of land use on soil $C$ storage, which ranged from $85.1 \mathrm{Mg} \mathrm{C}$ $\mathrm{ha}^{-1}$ in the pasture to $78.1 \mathrm{Mg} \mathrm{Cha}^{-1}$ and $76.1 \mathrm{Mg} \mathrm{C} \mathrm{ha}^{-1}$ in the silvopasture and woodland respectively (Table 2 ). However, when the analysis was calculated on an equivalent mass basis (Ellert and Bettany 1995), there was a significant difference $(P<0.001)$ among land use types. Soil $\mathrm{C}$ stocks in the pasture $\left(90.0 \mathrm{Mg} \mathrm{C}^{-1}\right)$ were greater than in the silvopasture (70.9 Mg Cha-1), and in the woodland (79.0 Mg Cha-1).

Table 1. Effect of land use type and soil depth on mean organic C content (g per $100 \mathrm{~g}$ of soil) measured in soils collected in June 2015.

\begin{tabular}{|c|c|c|c|c|}
\hline \multirow[b]{2}{*}{ Soil depth } & \multicolumn{3}{|c|}{ Land use } & \multirow[b]{2}{*}{$\begin{array}{c}\text { Mean } \\
(\%)\end{array}$} \\
\hline & $\begin{array}{c}\text { Pasture } \\
(\%)\end{array}$ & $\begin{array}{c}\text { Silvopastoral trees } \\
(\%)\end{array}$ & $\begin{array}{l}\text { Woodland } \\
\text { (\%) }\end{array}$ & \\
\hline $0-10 \mathrm{~cm}$ & 5.28 & 4.13 & 5.04 & 4.82 \\
\hline $10-20 \mathrm{~cm}$ & 3.72 & 2.96 & 2.85 & 3.17 \\
\hline Mean & 4.50 & 3.54 & 3.95 & 3.99 \\
\hline
\end{tabular}

Table 2. Effect of land use type and soil depth on organic $C$ stocks $\left(M g C \mathrm{Ca}^{-1}\right)$ assuming a fixed depth. Soils collected across the three land use types in June 2015.

\begin{tabular}{|c|c|c|c|c|}
\hline \multirow[b]{2}{*}{ Soil depth } & \multicolumn{3}{|c|}{ Land use } & \multirow[b]{2}{*}{$\begin{array}{c}\text { Mean } \\
\left(\mathrm{Mg} \mathrm{C} \mathrm{ha-1)}^{-1}\right)\end{array}$} \\
\hline & $\begin{array}{c}\text { Pasture } \\
\left(\mathrm{Mg} \mathrm{C} \text { ha }^{-1}\right)\end{array}$ & $\begin{array}{l}\text { Silvopastoral trees } \\
\qquad\left(\mathrm{Mg} \mathrm{Cha}^{-1}\right)\end{array}$ & $\begin{array}{l}\text { Woodland } \\
\left(\mathrm{Mg} \mathrm{C}_{\text {ha }}{ }^{-1}\right)\end{array}$ & \\
\hline $0-10 \mathrm{~cm}$ & 48.4 & 43.9 & 48.7 & 47.0 \\
\hline $10-20 \mathrm{~cm}$ & 36.7 & 34.2 & 27.4 & 32.8 \\
\hline Mean & 85.1 & 78.1 & 76.1 & 79.8 \\
\hline
\end{tabular}


The bulk density of soil samples collected in August 2015 was significantly higher $(P=0.01)$ in the silvopastoral system $\left(1.06 \pm 0.01 \mathrm{~g} \mathrm{~cm}^{-3}\right)$ than in the grassland $\left(1 \pm 0.01 \mathrm{~g} \mathrm{~cm}^{-3}\right)$ and woodland $\left(0.99 \pm 0.01 \mathrm{~g} \mathrm{~cm}^{-3}\right)$. The significant effects of soil depth were also evident in soil $\mathrm{C}$ content $(P=0.005)$, soil organic $C$ stocks $(P=0.0002)$, soil $N$ content $(P=0.01)$ and soil $N$ stocks $(P=0.0005)$, with significantly higher values in the $0-10 \mathrm{~cm}$ soil layer than at $10-20$ $\mathrm{cm}$. Once again the organic $C$ content $(\%)$ of bulk soil $(P=0.25)$ and the soil organic $C$ stocks $(P=0.7$; Fig. $2 a)$ did not significantly change across the three land use types. There were also no significant changes in the $\mathrm{N}$ content $(\%)$ of bulk soil $(\mathrm{P}=0.26)$ and soil $\mathrm{N}$ stocks (Fig. $2 \mathrm{~b})$ across the three land use types.

a)

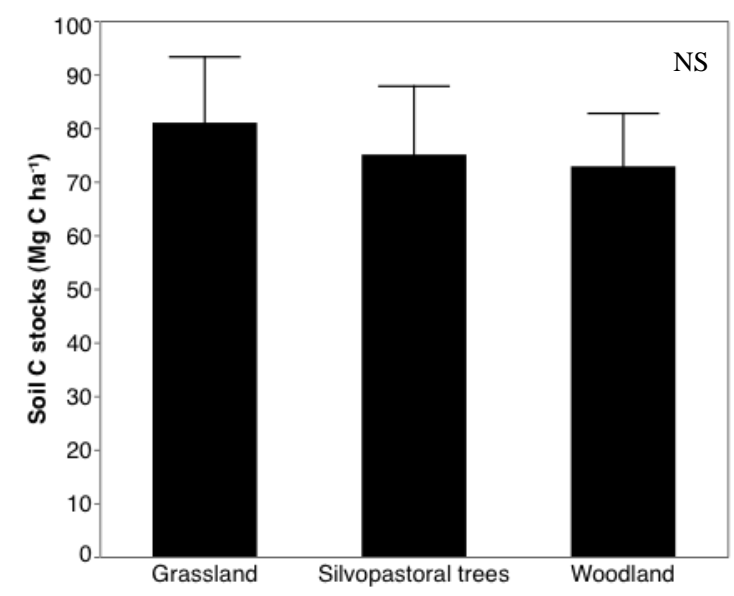

b)

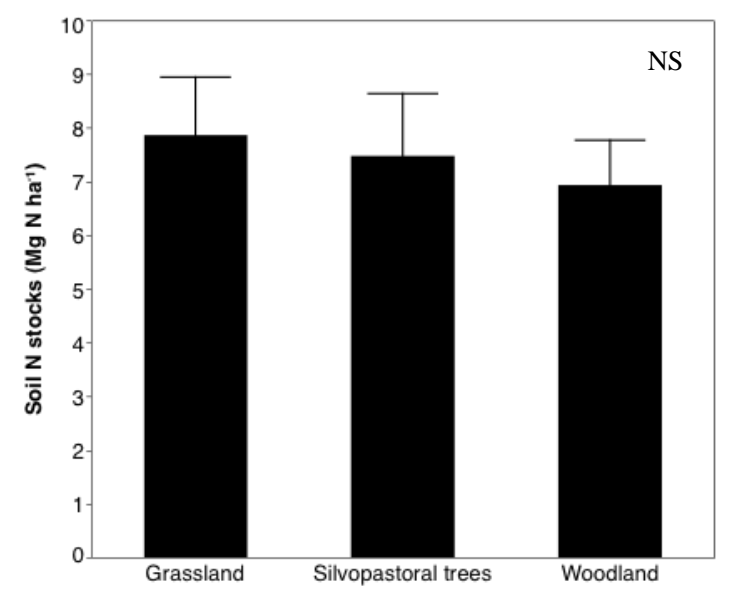

Fig. 2. Relationships between soil $C$ stocks (a) and soil $N$ stocks (b) and the three different land use types, which have been maintained for 26 years. Error bars show variation around the mean among plots under the same land use. NS = Not Significant.

Carbon and nitrogen content (\%) of different soil aggregate fractions

The average recovery rate associated with the initial mass of bulk soil $(100 \mathrm{~g})$ used for fractionation was $97.35 \pm 0.27 \%$ (silvopastoral), $97.56 \pm 0.25 \%$ (grassland), and $97.75 \pm 0.29$ $\%$ (woodland). It was found that land use type did not significantly affect the $\mathrm{C}$ content (\%) of large macro-aggregate $(P=0.35$; Fig. 3a), macro-aggregate $(P=0.31$; Fig. 3a), microaggregate $(P=0.82 ;$ Fig. $3 a)$, and silt $\&$ clay fractions $(P=0.25 ; F i g .3 a)$. Similarly land use type did not affect $\mathrm{N}$ content (\%) of the same soil physical fractions including large macroaggregate $(P=0.24$; Fig. $3 b)$, macro-aggregate $(P=0.22$; Fig. $3 b)$, micro-aggregate $(P=0.78$; Fig. $3 b)$ and silt \& clay $(P=0.3$; Fig. $3 b)$ fractions. Soil depth was significantly related to the $C$ content $(\%)$ of large-macro-aggregate $(P=0.02)$, macro-aggregate $(P=0.01)$, microaggregate $(P=0.0002)$, and silt \& clay $(P=0.001)$ fractions. In particular, all fractions separated from the $0-10 \mathrm{~cm}$ soil depth layer had higher $C$ content (\%) than deeper soils (10$20 \mathrm{~cm}$ soil depth). The same trend was observed for $\mathrm{N}$ content (\%), which was not affected by land use type ( $P>0.2$ for all analyses) but was significantly higher in topsoil layers for large macro-aggregate $(P=0.03)$, macro-aggregate $(P=0.02)$, micro-aggregate $(P=0.0004)$, and silt \& clay $(P=0.001)$ fractions. 
a)

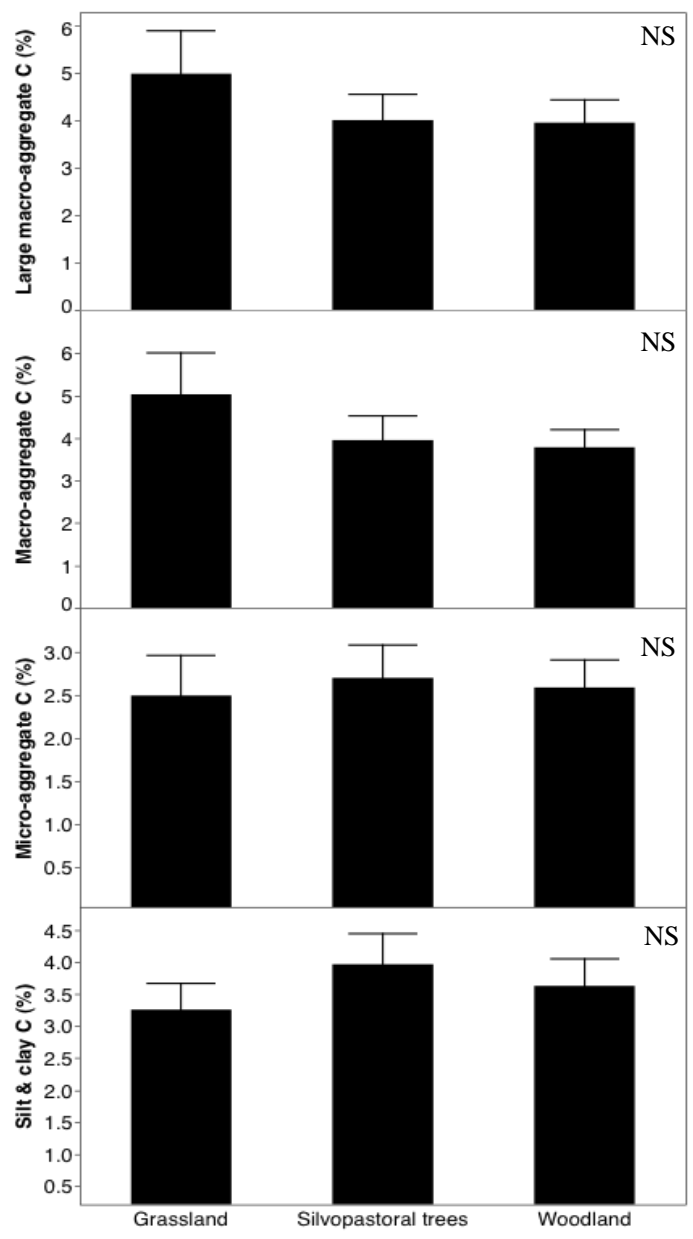

b)

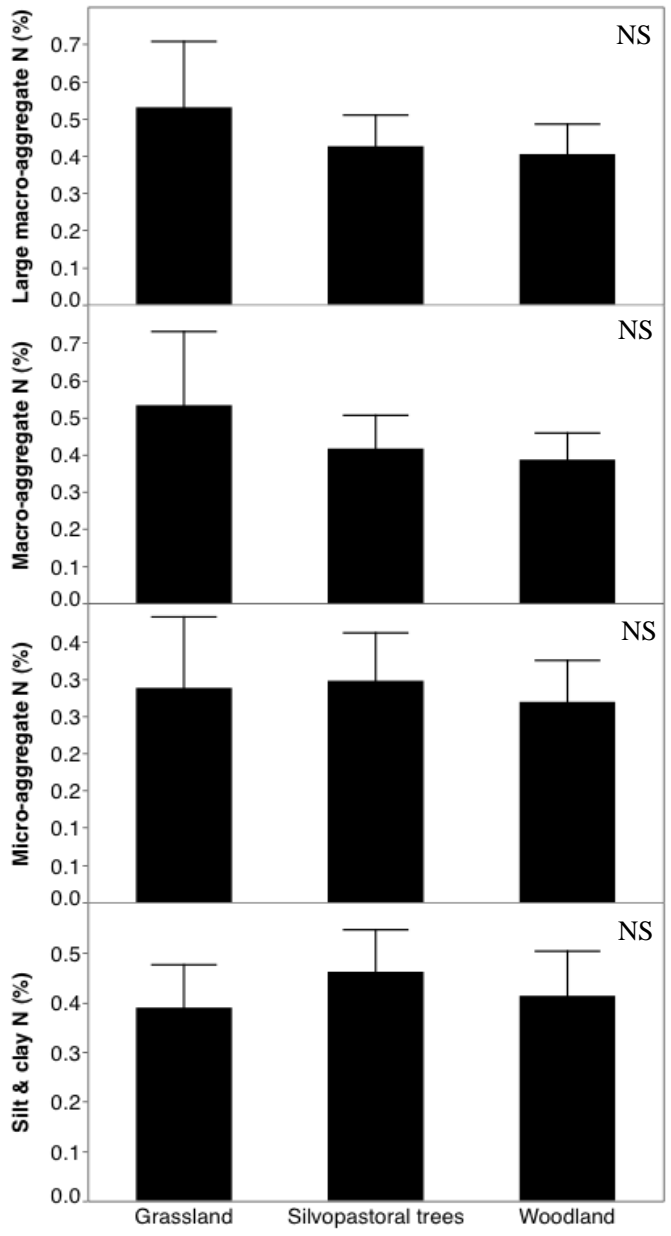

Fig. 3. Relationships between the $C(a)$ and $N$ content (b) of different soil fractions (at $0-10$ and $10-20$ $\mathrm{cm}$ depth) and three different land use types. Large macro-aggregates ( $>2 \mathrm{~mm}$ ), macro-aggregates (2 $\mathrm{mm}-250 \mu \mathrm{m})$, micro-aggregates $(250-53 \mu \mathrm{m})$ and Silt \& Clay $(<53 \mu \mathrm{m})$. Error bars show variation among plots under the same land use. NS = not significant.

Carbon and nitrogen pools of different soil aggregate fractions

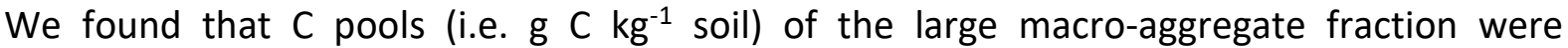
significantly higher under permanent grassland $\left(23.7 \pm 4.6 \mathrm{~g} \mathrm{C} \mathrm{kg}^{-1}\right.$ soil; $\left.\mathrm{P}=0.03\right)$ than under silvopastoral trees (14.9 $\pm 2.8 \mathrm{~g} \mathrm{C} \mathrm{kg}^{-1}$ soil) or woodland (13.4 $\pm 2.3 \mathrm{~g} \mathrm{C} \mathrm{kg}^{-1}$ soil; Fig. 4a). Soil $\mathrm{C}$ pools of the macro-aggregate fraction did not change across land use types (Fig. 4b), however, C pools of micro-aggregate and silt \& clay fractions were significantly lower $(P<$ 0.05 ) in the permanent grassland when compared to silvopasture and woodland (Fig. 4c, d). Soil $C$ pools of the large macro-aggregate fractions were significantly higher in top-soils ( 0 $10 \mathrm{~cm}$ ) when compared to deeper soils $(10-20 \mathrm{~cm}, \mathrm{P}=0.004$; Fig. 4a). No soil depth effects were found in the $C$ pools of other soil physical fractions $(P>0.5)$. 
a)

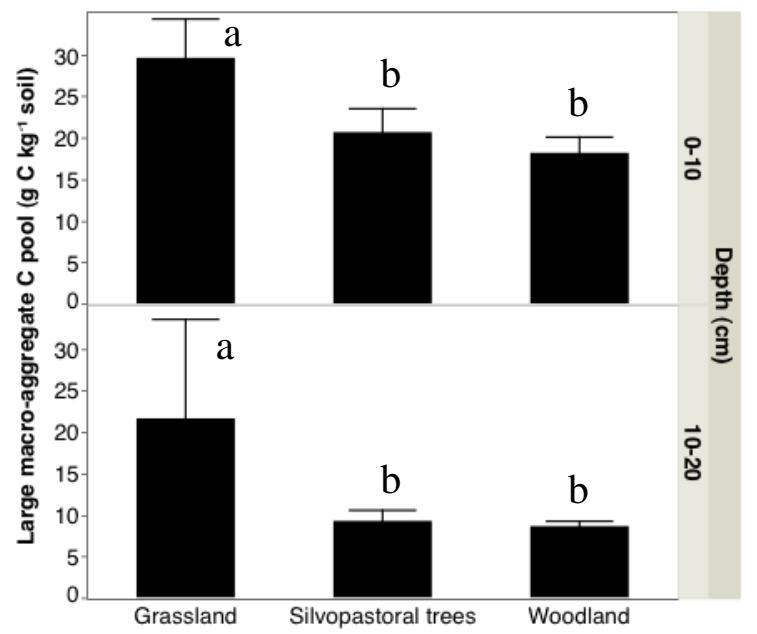

c)

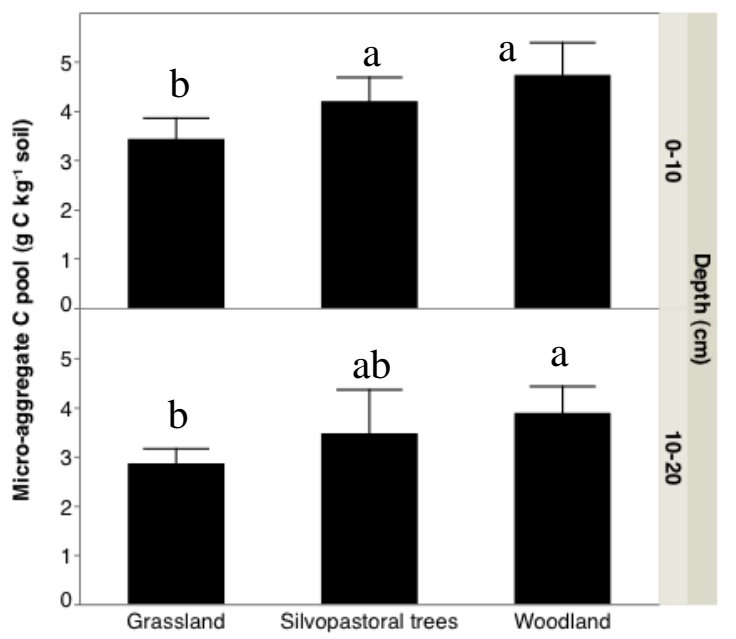

b)

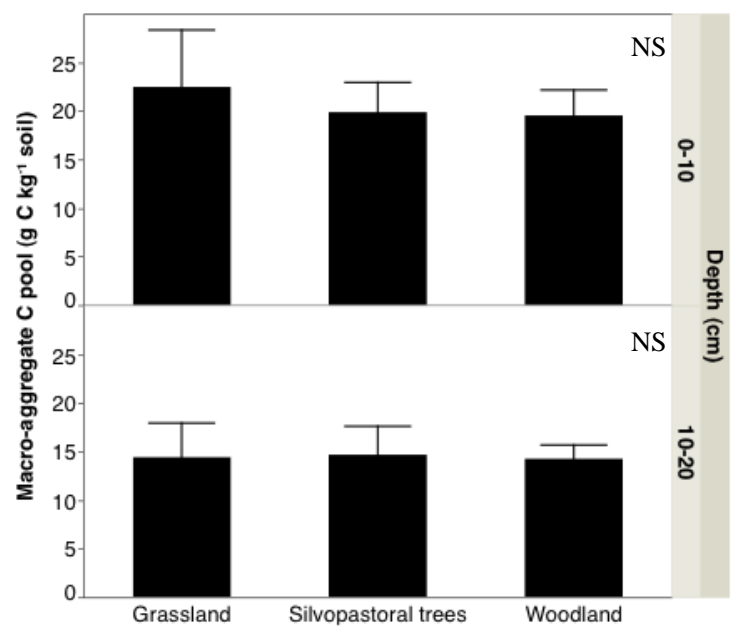

d)

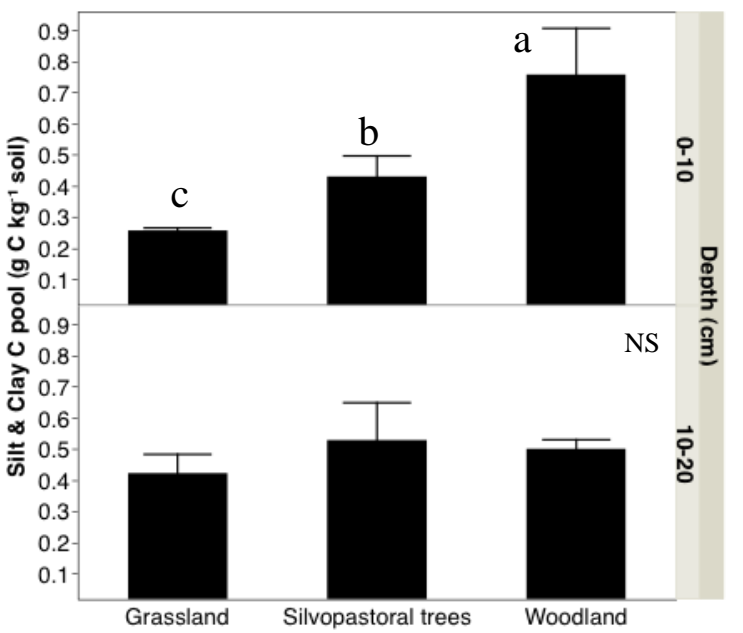

Fig. 4. C pools ( $\mathrm{g} \mathrm{C} \mathrm{kg}^{-1}$ soil) of four different soil aggregate fractions and the three land use types within two different soil depths (0-10 and $10-20 \mathrm{~cm}$ depth). Large macro-aggregates $(>2 \mathrm{~mm})$, macro-aggregates $(2 \mathrm{~mm}-250 \mu \mathrm{m})$, micro-aggregates $(250-53 \mu \mathrm{m})$ and Silt \& Clay $(<53 \mu \mathrm{m})$. Error bars show variation among plots under the same land use type; different letters indicate a significant difference.

Total mass of the large macro-aggregate fraction (i.e. grams of the soil fraction per $100 \mathrm{~g}$ of bulk soil) was significantly higher in the permanent grassland when compared with the silvopastoral and woodland ecosystems (Fig. 5a). In particular in the grassland ecosystem the mass of the large macro-aggregate fraction was $47.9 \pm 3 \mathrm{~g}$ of the bulk soil mass (i.e. based on $100 \mathrm{~g}$ of bulk soil) when compared to $36.3 \pm 2.9 \mathrm{~g}$ of the silvopastoral system and $33.3 \pm 2.9 \mathrm{~g}$ of the woodland $(\mathrm{P}=0.01)$. By contrast, the total mass of the macro-aggregate soil fraction significantly decreased in the permanent grassland $(37.3 \pm 1.9 \mathrm{~g})$ when compared to the silvopastoral (44.4 $\pm 1.8 \mathrm{~g})$ and the woodland systems (45.1 $\pm 1.9 \mathrm{~g})(\mathrm{P}=$ 0.001 ; Fig. $5 b)$. The mass of the micro-aggregate fraction was significantly lower in the 
permanent grassland $(11 \pm 1.5 \mathrm{~g})$ when compared with silvopastoral $(14.7 \pm 1.3 \mathrm{~g})$ and woodland systems (17.3 $\pm 1.22 \mathrm{~g})(P=0.03$; Fig. $5 \mathrm{c})$. Finally, the mass of the silt \& clay fraction also increased from permanent grassland to silvopastoral and woodland systems (Fig. 5d).

a)

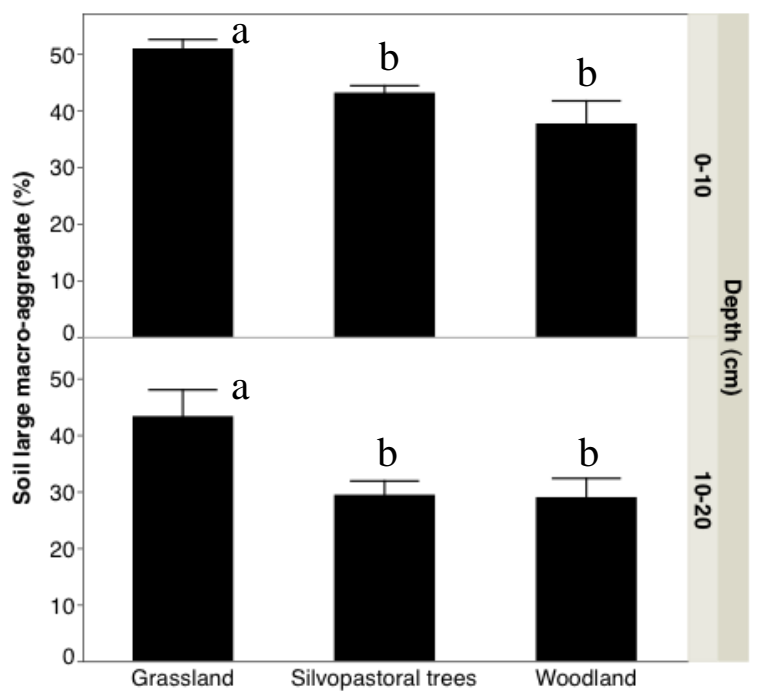

c)

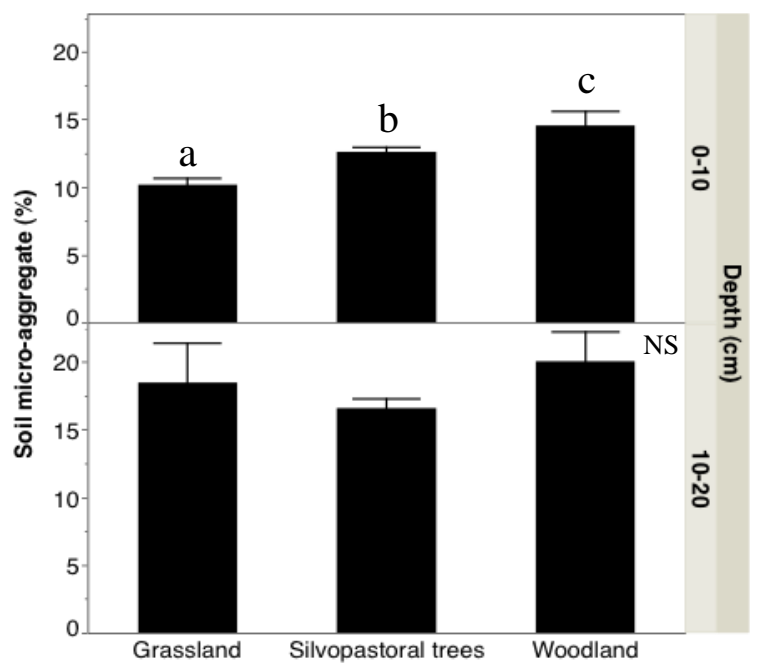

b)

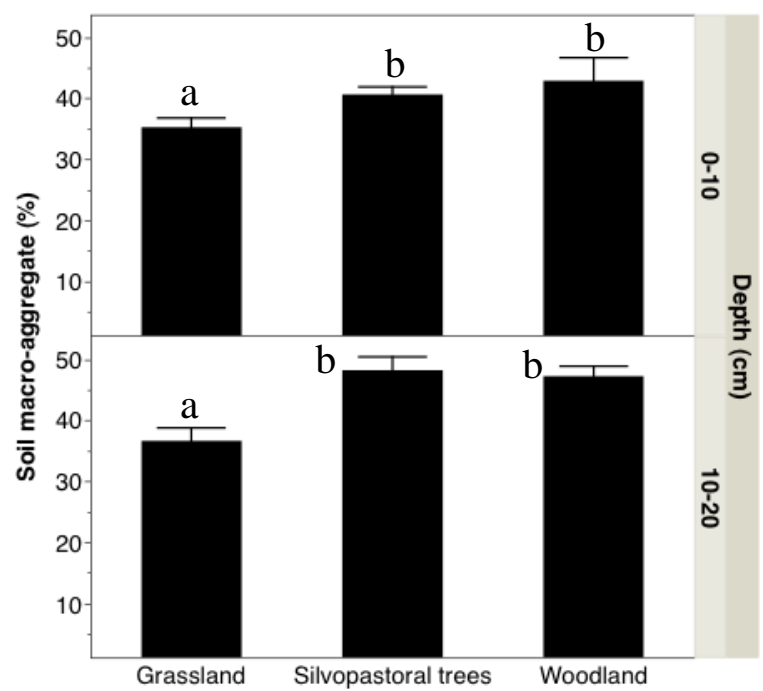

d)

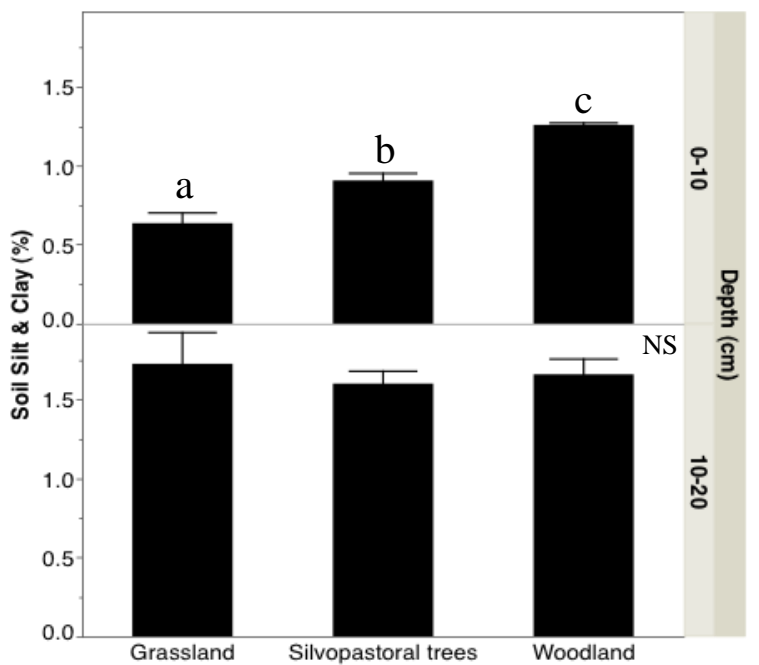

Fig. 5. Relationships between total mass of each of the four soil aggregate fractions and the three land use types within two different soil depths (0-10 and 10-20 cm depth). Note that mass of each aggregate fraction is expressed in percentage, which represents the relative contribution of each fraction dry weight to 100 grams of bulk soil. Error bars show variation among plots under the same land use type. 


\section{Discussion}

Soil bulk density

We found that soil bulk density was significantly higher in the silvopastoral system than in the woodland or permanent grassland. This could be partly explained by compaction caused by animal grazers (i.e. sheep), which can increase soil bulk density by $10-15 \%$ when compared to woodland systems (Chanasyk and Naeth 1995). However, this does not explain the difference between the permanent grassland and the silvopastoral system. A possible reason for the high soil bulk density in the silvopasture plots is that these soils are usually drier than the grassland soils. For example, Upson et al. (2016) showed that for a clay soil in Bedfordshire UK, soil bulk density decreased by $0.017 \mathrm{~g} \mathrm{~cm}^{-3}$ for each additional $1 \mathrm{~g}$ of water per $100 \mathrm{~g}$ of soil. Greater water use by widely spaced trees in our silvopastoral system could have reduced soil moisture content. Because the clay component of our soils is significant $(\approx$ $40 \%$ ), it could be that the shrinking of these drier soils (compared to the grassland soils) has determined an increase in soil bulk density.

Soil carbon stocks

When calculated on a fixed depth basis, there was no statistically significant effect of planting trees on soil C content or on soil C stocks. Beckert et al. (2016) also reported no change in soil $C$ stocks between a control pasture system, woodland ( 2500 tree ha ${ }^{-1}$ ) and multiple silvopastoral systems $\left(400\right.$ tree ha $\left.^{-1}\right) 24$ years after planting in North East Scotland. In a meta-analysis of seven studies, Hoogmoed et al. (2012) also reported no significant changes in soil $\mathrm{C}$ stocks within the first 30-years of afforestation programmes on grassland under Mediterranean climatic conditions in Australia. Poeplau et al. (2011) and Bárcena (2014) have also undertaken meta-analyses that show no evidence of significant soil C accumulation following afforestation of grasslands.

In our study when soil $C$ stocks were calculated on an equivalent mass basis (Ellert and Bettany, 1995), we found that C stocks were lower under the silvopastoral system when compared to the permanent grassland. Wuest (2009) argues that calculations on a mass basis are more accurate when there is a need to remove the confounding effect of compaction between treatments.

Although this study has examined a silvopastoral and woodland system over 26 years, it is possible that the full effect of land use is only detected when considering longertime scales (>30 years) depending on the tree species ( $\mathrm{Li}$ et al. 2012). For example, the presence of $\mathrm{N}$-fixing woody species could lead in the long-term to significant increases in soil C pools (Resh et al. 2002). Hoogmoed et al. (2012) in their meta-analysis indicated that whilst there was no difference between the soil $C$ below pasture and woodland under 30 years old, the soil $\mathrm{C}$ was greater in very old woodlands (i.e. about 150 years old).

Soil aggregate fractions

Contrary to our prediction we found that $\mathrm{C}$ pools ( $\mathrm{g} \mathrm{C} \mathrm{kg}^{-1}$ soil) of the large macro-aggregate fraction were significantly lower under the silvopastoral and planted woodland (Fig. 4a) than 
under permanent grassland. Soil $\mathrm{C}$ pools of the macro-aggregate fractions were also higher (although not significantly) in the permanent grassland. By contrast $\mathrm{C}$ pools of both microaggregate and silt \& clay fractions were significantly higher in the silvopastoral and woodland systems than the permanent grassland. Thus despite no statistical changes in soil $C$ stocks there was a relative 'shift' in the size of different $C$ pools across the three land-use types. Whilst the grassland soils had 'high' $\mathrm{C}$ pools of the large macro-aggregate fractions and 'lower' $C$ pools of the microaggregate and silt \& clay fractions, the silvopastoral and woodland systems had shifted the balance of the $C$ pools from the macro-aggregates to the smaller fractions.

These results agree with those of Gelaw et al. (2013), who reported higher C pools in soil macro-aggregates (i.e. $>250 \mu \mathrm{m}$ ) from permanent grassland than those in silvopastoral systems in Ethiopia. Our results also confirm findings from a transect study of three agroecosystems across 35 sites in central Alberta, Canada, which show positive agroforestry effects on the $C$ pool of micro-aggregate as well as silt \& clay fractions (Baah-Acheamfour et al. 2014). Previous agroforestry studies across different climatic conditions also show that tree planting in the long-term contributes to increases in the $C$ pool of both soil microaggregate and silt \& clay fractions (Haile et al. 2010; Hoosbeek et al. 2016; Osei et al. 2017). Our findings, also agree with those from a recent study in the UK (Beckert et al. 2016), which show that the $C$ pool of silt and clay fractions is lower in pasture soils when compared to different silvopastoral systems. However, the same study shows that other recalcitrant $C$ pools may not differ between pasture and silvopastoral systems, suggesting that differences in soil fractionation methods (i.e. physical vs. density fractionation) and in tree species identity (i.e. ash vs. sycamore vs. scots pine) may add significant variability to $C$ accumulation and stabilization processes into different soil fractions.

In our study the observation that the silvopastoral and woodland system showed high $C$ pools in the micro-aggregate and silt and clay fractions could be a result of high deposition of broadleaf litter. Greater litter inputs may have stimulated microbial activity and hence led to greater organic matter degradation than in the grassland system ultimately determining greater accumulation and stabilization of $\mathrm{C}$ into smaller aggregate fractions (Prescott 2010). The higher $C$ pools in the two smaller soil fractions found in the woodland rather than the silvopastoral system (where the understorey is grazed) (Fig. 4c, d) may be a result of the woodland receiving more plant detritus than the ash silvopastoral system.

Evidence from this study suggests that shifts in soil $\mathrm{C}$ pools of different aggregate fractions across land use types were more related to changes in soil 'aggregate mass' rather than in soil 'aggregate C content' (Fig. 5). This suggests that within both silvopastoral and planted woodland systems more organic matter has been processed by macrofauna and soil microbes thus increasing detritus inputs into smaller soil aggregates. For example Del Galdo et al. (2003) and De Gryze et al. (2004) have shown how afforestation can promote an increase of $C$ in more protected microaggregate $(53-250 \mu \mathrm{m})$ soil fractions and that this might be seen as an indicator of long-term $C$ accumulation, especially if these soil fractions accumulate in deeper soils (Howlett et al. 2011). 
Overall, our results show how soil C (and N) stocks do not change after almost three decades since a significant land use change from permanent grassland to either silvopastoral or woodland management systems. We observed, however, significant changes in both soil aggregate mass and the soil $\mathrm{C}$ pool of different aggregate fractions. Large macro-aggregate $C$ pools were greater in permanent grasslands whereas microaggregate and silt \& clay C pools were greater in silvopastoral and woodland systems. Further studies could address what underlying biogeochemical mechanisms might be responsible for soil aggregate changes and whether the accumulation of $C$ into smallerrecalcitrant fractions is an indicator of long-term $C$ sequestration in silvopastoral soils.

\section{Acknowledgements}

This research was funded by the Department of Agriculture, Environment \& Rural Affairs (DAERA) of Northern Ireland (UK) - project number 15/4/03 (48073), and the AGFORWARD project (613520) funded by the European Commission. The authors gratefully acknowledge field and laboratory assistance of Ian Doods, Frances Ward, Elizabeth Mulligan, ElizabethAnne and Alan Wright, and statistical support from Silvestre Garcia de Jalon.

\section{References}

Avery BW (1980) Soil Classification for England and Wales (Higher Categories). Soil Survey Technical Monograph No. 14 Harpenden.

Baah-Acheamfour M, Carlyle CN, Bork EW, Chang SX (2014) Trees increase soil carbon and its stability in three agroforestry systems in central Alberta, Canada. For Ecol Manag 328:131-139

Bárcena TG, Kiær LP, Vesterdal L, Stefánsdóttir HM, Gundersen P, Sigurdsson BD (2014) Soil carbon stock change following afforestation in Northern Europe: a meta-analysis. Glob Chan Biol 20:2393-2405

Beckert MR, Smith P, Lilly A, Chapman SJ (2016) Soil and tree biomass carbon sequestration potential of silvopastoral and woodland-pasture systems in North East Scotland. Agrofor Syst 90:371-383

Bommarco R, Kleijn D, Potts SG (2013) Ecological intensification: harnessing ecosystem services for food security. Trends Ecol Evol 28:230-238

Cambardella CA, Elliott ET (1993) Carbon and nitrogen distribution in aggregates from cultivated and native grassland soils. Soil Sci Soc Am J 57:1071-1076

Cardinael R, Chevallier T, Barthès BG, Saby NPA, Parent T, Dupraz C, Bernoux M, Chenu C (2015) Impact of alley cropping agroforestry on stocks, forms and spatial distribution of soil organic carbon - a case study in a Mediterranean context. Geoderma 259260:288-299

Cardinael R, Chevallier T, Cambou A, Béral C, Barthès BG, Dupraz C, Durand C, Kouakoua E, Chenu $C$ (2017) Increased soil organic carbon stocks under agroforestry: A survey of six different sites in France. Agr Ecosyst Environ 236:243-255

Chanasyk DS, Naeth MA (1995). Grazing impacts on bulk density and soil strength in the 
foothill fescue grasslands of Alberta, Canada. Canadian Journal of Soil Science 75: 551-557.

Cruickshank JG (1997) Soil and environment: Northern Ireland Agricultural and Environment Science Division, DANI and the Agricultural Environmental Science Department, The Queen's University Belfast. 77 pages.

Del Galdo L, Six J, Peressotti A, Cotrufo MF (2003) Assessing the impact of land-use change on soil $C$ sequestration in agricultural soils by means of organic matter fraction and stable C isotopes. Glob Chan Biol 9:1204-1213

De Gryze S, Six J, Paustian K, Morris SJ, Paul EA, Merckx R (2004) Soil organic carbon pool changes following land use conversions. Glob Chan Biol 10:1120-1132

Ellert B, Bettany J. 1995. Calculation of organic matter and nutrients stored in soils under contrasting management regimes. Can. J. Soil Sci. 75 (4): 529-538.

FAO and ITPS. 2015. Status of the World's Soil Resources (SWSR) - Technical Summary. Food and Agriculture Organization of the United Nations and Intergovernmental Technical Panel on Soils, Rome, Italy

Fischer J, Brosi B, Daily GC, Ehrlich PR, Goldman R, Goldstein J, Lindenmayer DB, Manning AD, Mooney HA, Pejchar L, Ranganathan J, Tallis H (2008) Should agricultural policies encourage land sparing or wildlife-friendly farming? Front Ecol Env 6(7):380-385

Gelaw AM, Singh BR, Lal R (2015) Organic carbon and nitrogen associated with soil aggregates and particle sizes under different land uses in Tigray, Northern Ethiopia. Land Degrad Dev 26:690-700.

Guo LB, Gifford RM (2002) Soil carbon stocks and land use change: a meta analysis. Glob Chan Biol 8:345-360

Haile SG, Nair VD, Nair PKR (2010) Contribution of trees to carbon storage in soils of silvopastoral systems in Florida, USA. Glob Chan Biol 16:427-438

Hoogmoed M, Cunningham SC, Thomson JR, Baker PJ, Beringer J, Cavagnaro TR (2012) 'Does afforestation of pastures increase sequestration of soil carbon in Mediterranean climates?' Agr Ecosyst Environ 159:176-183

Hoosbeek MR, Remme RP, Rusch GM (2016) Trees enhance soil carbon sequestration and nutrient cycling in a silvopastoral system in south-western Nicaragua. Agrofor Syst doi:10.1007/s10457-016-0049-2

Howlett DS, Mosquera-Losada MR, Nair PKR, Nair VD, Rigueiro-Rodríguez A (2011) Soil carbon storage in silvopastoral systems and a treeless pasture in Northwestern Spain. J Environ Qual 40:825-832

Huang Z, Davis MR, Condron LM, Clinton PW (2011) Soil carbon pools, plant biomarkers and mean carbon residence time after afforestation of grassland with three tree species. Soil Biol. Biochem. 43:1341-1349

Laganière J, Angers DA, Paré D (2010) Carbon accumulation in agricultural soils after afforestation: a meta-analysis. Glob Chan Biol 16:439-453

Li DZ, Niu SL, Luo YQ (2012) Global patterns of the dynamics of soil carbon and nitrogen stocks following afforestation: a meta-analysis. New Phytol 195:172-181 
Montagnini F, Nair PKR (2009) Carbon sequestration: An underexploited environmental benefit of agroforestry systems. Agrofor Syst 61:281-295

Mosquera-Losada MR, McAdam JH, Romero-Franco R, Santiago-Freijanes JJ, RigueiroRodríguez A 2009. Definitions and components of agroforestry practices in Europe. In: Rigueiro-Rodríguez, A., McAdam, J., Mosquera-Losada, M.R. (Eds.), Agroforestry in Europe Current Status and Future Prospects, 3-19. Springer Science + Business Media B.V., Dordrecht.

Oelbermann M, Paul Voroney R, Gordon AM (2004) Carbon sequestration in tropical and temperate agroforestry systems: a review with examples from Costa Rica and southern Canada. Agr Ecosyst Environ 104:359-377

Osei AK, Kimaro AA, Peak D, Gillespie AW, Van Rees KCJ (2017) Soil carbon stocks in planted woodlots and Ngitili systems in Shinyanga, Tanzania. Agrofor Syst doi:10.1007/s10457-016-0028-7

Paul K, Polglase P, Richards G (2003) Predicted change in soil carbon following afforestation or reforestation, and analysis of controlling factors by linking a $\mathrm{C}$ accounting model (CAMFor) to models of forest growth (3PG), litter decomposition (GENDEC) and soil C turnover (RothC). For Ecol Manag 177:485-501

Phalan B, Onial M, Balmford A, Green RE (2011) Reconciling food production and biodiversity conservation: land sharing and land sparing compared. Science 333:1289-1291

Poeplau C, Don A, Vesterdal L, Leifeld J, VanWesemael B, Schumacher J, Gensior A (2011) Temporal dynamics of soil organic carbon after land-use change in the temperate zone - carbon response functionsas a model approach. Glob Chan Biol 17:2415-2427

Prescott CE (2010) Litter decomposition: what controls it and how can we alter it to sequester more carbon in forest soils? Biogeochem 101:133-149

Nair PKR, Nair VD, Kumar BM, Haile SG (2009) Soil carbon sequestration in tropical agroforestry systems: a feasibility appraisal. Environ Sci Policy 12:1099-1111

Resh SC, Binkley D, Parrotta JA (2002) Greater soil carbon sequestration under nitrogenfixing trees compared with Eucalyptus species. Ecosyst 5:217-231

Shi S, Zhang W, Zhang P, Yu Y, Ding F (2013) A synthesis of change in deep soil organic carbon stores with afforestation of agricultural soils. For. Ecol. Manag. 296:53-63.

Sibbald AR, Eason WR, McAdam JH, Hislop AM (2001) The establishment phase of a silvopastoral national network experiment in the United Kingdom. Agrofor Syst 39:39-53

Tisdall JM, Oades J M (1982) Organic matter and water-stable aggregates in soils. J. Soil Sci. 33:141-163

Torralba M, Fagerholm N, Burgess PJ, Moreno G, Plieninger T (2016) Do European agroforestry systems enhance biodiversity and ecosystem services? A meta-analysis. Agr Ecosyst Environ 230:150-161

Tully KL, Lawrence D, Scanlon TM (2012) More trees less loss: nitrogen leaching losses decrease with increasing biomass in coffee agroforests. Agr Ecosyst Environ 
161:137-144

Upson MA, Burgess PJ (2013) Soil organic carbon and root distribution in a temperate arable agroforestry system. Plant Soil 373:43-58

Upson MA, Burgess PJ, Morison JIL (2016) Soil carbon changes after establishing woodland and agroforestry trees in a grazed pasture. Geoderma 283:10-20

von Lützow M, Kögel-Knabner I, Ekschmitt K, Flessa H, Guggenberger G, Matzner E, Marschner B (2007) SOM fractionation methods: Relevance to functional pools and to stabilization mechanisms. Soil Biol Biochem 39:2183-2207

Wuest SB (2009) Correction of bulk density and sampling method biases using soil mass per unit area. Soil Sci Soc Am J 73:312-316 